\title{
Glycine-tRNA Ligase
}

National Cancer Institute

\section{Source}

National Cancer Institute. Glycine-tRNA Ligase. NCI Thesaurus. Code C132129.

Glycine-tRNA lig ase (739 aa, $\sim 83 \mathrm{kDa}$ ) is encoded by the human GARS gene. This protein plays a role in tRNA aminoacylation. 